\title{
Foreign Direct Investment as a Factor of Economic Growth in Poland. Empirical Analysis for the Period 1995-2012
}

\author{
Aneta Kosztowniak \\ Faculty of Economics, Radom University of Technology and Humanities, 26-600 Radom, Poland \\ *Corresponding Author: aneta.kosztowniak@wp.pl
}

\begin{abstract}
The main purpose of this paper is to analyse significance of the production factors on economic growth in Poland in the years 1995-2012, with particular attention given to the influence of foreign direct investments (FDI). The analysis was carried out with the use of the Cobb-Douglas production function. This paper describes two models. The first, basic model of the economic growth for Poland consists of four variables and the second - augmented model - consists of six independent variables. The research conducted in Poland reveals that in the period 1995-2012 a linear correlation existed between the FDI inflow and growth (Pearson's coefficient $\mathrm{R}=0.8317$ ), however, according to a model estimated with the use of the CLS method, FDI was not a significant factor determining GDP growth. The really significant factors were gross domestic expenditure on fixed capital and expenditure on R\&D. The augmented version of the Cobb-Douglas function model for the years 1995-2012 estimated by means of the CLS method demonstrates that the only significant factor was government spending at $5 \%$ significance level. The remaining variables were insignificant.
\end{abstract}

Keywords Foreign Direct Investment, Economic Growth, Cobb-Douglas Production Function, Poland, CEE countries

\section{Introduction}

The systemic transformation processes undertaken by the Central and Eastern Europe (CEE) countries at the beginning of the 1990s were connected, among others with liberalization of capital flows which was to support these countries in their economic growth. What was important for the said countries was to raise foreign capital, especially in the form of foreign direct investment (FDI) which was a form of a complex capital transfer. Focusing on this form of capital resulted chiefly from a low rate of internal accumulation in CEE countries, restructuring needs of their economies, privatization, infrastructure development and raising funds for implementation of structural reforms.

An attempt to assess the FDI impact on economic growth was made using the case of one country which started systemic transformations in 1989, namely Poland.

The main purpose of the paper is to investigate significance of the factors of production on economic growth in Poland in the years 1995-2012, with particular attention given to the influence of FDI.

The data of the National Bank of Poland[1] and UNCTAD[2] concerning FDI inflows and outflows in Poland over the period 1995-2012 indicate that in the 1990s these flow were characterized by a relatively stable upward trend.

However, in the 2000s strong short-term fluctuations occurred, both upward and downward. The FDI inflows to Poland increased from USD 3659 million in 1995 to USD 9445 million in 2000. During the period 2001-2012 which was characterized by a fairly strong amplitude of changes, the upward trends in FDI inflows covering the years 2002-2004, 2006-2007 and 2011. The highest value of FDI inflows was noted in Poland in 2007 and it stood at the level of USD 23561 million. What is more, while comparing the absolute values of FDI inflows in the entire market of the CEE countries it is evident that Poland was the main destination of FDI inflows next to such countries as Hungary, Czech Republic or Slovakia.

The role of Poland as an exporter was negligible but it was growing in the 2000s. An increase in the value of Polish foreign investments was noted in the years 2002-2011. At that period it grew from USD 229 million to USD 7211 million, reaching the record level of USD 8883 million in 2006. In 2012 disinvestment occurred, i.e. a withdrawal of capital from abroad and repatriation of Polish investors' profits at the level of USD 894 million.

Over the entire analyzed period Poland was a net FDI importer. The balance of net FDI flows amounted to USD 3617 million in 1995 reaching USD 9428 million in 2000 and then USD 11974 million in 2004, USD 18156 million in 2007 and USD 4250 million in 2012.

Like in other CEE countries, the 2001-2002 recession, the EU accession in 2004 and the outbreak and occurrence 
of the global financial crisis entailed changeability in FDI inflows and outflows in Poland (Figure 1).

While analyzing the relative size of FDI inflows to Poland in the years 1995-2011 it must be noted that percentage of these inflows to Poland in global FID inflows oscillated around $1.0 \%$. This percentage stood at $1.07 \%$ in 1995 falling to $0.99 \%$ in 2011 . Poland reached the highest FDI inflow in comparison to global inflows (1.73\%) in 2004. In the case of other CEE countries in the years 1995-2011 these shares stood at $1.49 \%$ and $0.31 \%$ respectively for Hungary, $0.75 \%$ and $0.35 \%$ for the Czech Republic, $0.75 \%$ and $0.14 \%$ for Slovakia and $0.04 \%$ and $0.06 \%$ for Slovenia.

While analyzing FDI inflows to the countries undergoing transformations (including CEE countries) in global inflows of these investments, the importance of this group of countries was growing. According to UNCTAD their share in global FDI inflows had grown from $0.33 \%$ in 1995 to $3.70 \%$ in 2011.

The UNCTAD[2] data concerning the FDI inflow to GDP ratio in the years 1995-2011 indicate that the inflow was relatively low taking the economic potential of Poland into consideration. This ratio for Poland stood at $2.63 \%$ in 1995 and $2.95 \%$ in 2011 at the growth of $5.09 \%$ in $2004,5.74 \%$ in 2006 and 5.54\% in 2007. In the case of the Czech Republic the FDI inflow to GDP ratio was $4.43 \%$ in 1995 and $2.50 \%$ in 2011 reaching the highest value of $10.81 \%$ in 2002 . In Hungary this ratio stood at $11.19 \%$ in 1995 and fell to $4.18 \%$ in 2004 and $3.35 \%$ in 2011. In Slovakia in the years $1995-2011$ the ratios were $13.21 \%$ and $2.23 \%$, respectively, whereas for Slovenia $-0.72 \%$ and $2.02 \%$, respectively[2].

The National Bank of Poland's[3] data concerning the international position of Poland as far as investments are concerned in the years 1995-2012 indicate that the value of inward FDI stock amounted to USD 7843 million in 1995 and grew reaching USD 233355 million in 2012. As regards the value of outward FDI stock, in the examined period it grew from USD 539 million USD to USD 57144 million.

\section{FDI and Economic Growth - Theoretical Background}

Majority of existing theoretical models imply that FDI is beneficial for a host country's economic growth. According to the traditional economic theory (law of diminishing returns), FDI tends to concentrate in less developed countries, where there are better opportunities to achieve higher returns; despite this theory empirical results showed that more than two-thirds of the world's FDI stock is hosted in developed countries.

Some authors argue that there are several potential ways in which FDI can influence economic growth. Growth models started with the neoclassical models (Solow and Swan)[4] in the 1960s and relied on capital and labour, FDI being considered not to influence long-term economic growth, but only the income level. In neo-classical growth models FDI increases the capital stock and finance capital formation contributing to economic growth. In this case the effects of foreign investments are the same as the influence of domestic capital. Yet, these models assume only a short-term effect on economic growth, due to the diminishing returns on capital.

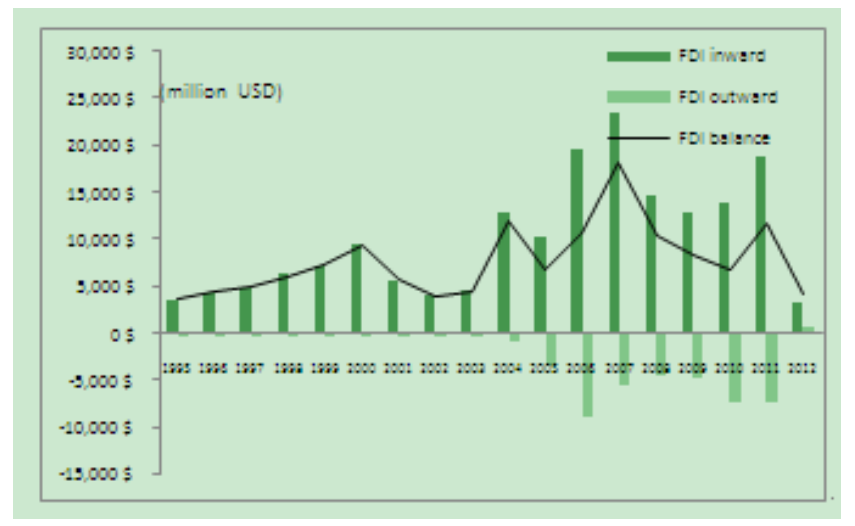

Source: authors 's own calculations on the basis of NBP[1] and UNCTAD[2] Figure 1. Inward and outward FDI flows and balance in Poland in the period 1995-2012

On the other hand, in the new growth theory FDI is assumed to have a positive impact on economic growth both in short- and long-run. Herzer, Klasen and Howak-Lehmann[5] argue that FDI is more productive than domestic capital and the impact of diminishing returns on capital which is related to spillover effects is low and economy continues to grow in the long run.

However, the causality relation between FDI and growth is not necessarily unidirectional; causality can work in both directions. The standard economic theory accounts for FDI influence on growth. The reverse causality (i.e. from economic growth to FDI) is based on the process of "cumulative causation" that in the long run causes that the economic growth based on the development of capital stock may create new economic activities and a higher demand for new consumer products that will attract an increased level of FDI.

Moreover, some theoretical papers imply that the positive correlation between FDI and growth is not necessarily true. For example, Herzer, Klasen and Howak-Lehmann[5] argue that if FDI considerably "crowd out" domestic investments, then a growth decelerating impact on the recipient country is possible.

According to Aizenmam and Noy[6] a positive impact of FDI inflow on economic growth depends on various factors such as the human capital, the degree of trade openness, the depth of financial market, or the income per capita. De Mello[7] mentions also domestic infrastructure. These prerequisites seem to be of high importance when it comes to FDI inflows to less developed countries and have a measurable impact on economic growth. Indeed, lack of these preconditions in several developing countries has resulted in unequal distribution across countries, with several developing countries facing difficulties to attract foreign 
investors (Addison and Heshmati[8]).

\section{FDI and Economic Growth - Review of Selected Empirical Studies}

Many empirical studies have led to conflicting results regarding the role and impact of FDI on host states. In general, when we speak of the link between FDI and economic growth we usually assume that FDI influences the growth rate. Such a hypothesis is based on the ability of foreign direct investment to influence the growth factors such as: investment, technological progress or human capital. But the link FDI - economic growth link may be a bi-directional one, rapid economic growth leading to an increase in FDI (Vintila, Zaharia)[6].

Furthermore, most results of econometric models demonstrate a relatively low though positive impact of FDI on economic development in surveyed countries. These results show that the ability of individual economies to use positive externalities related to the inflow of foreign direct investments is limited by conditions prevailing in the host country.

Balasubramanyam, Salisu and Sapsford[10] analyze the impact of FDI on economic growth in developing economies using ordinary least squares (OLS). The results of these tests show the positive impact of foreign direct investments on economic growth in developing countries applying the export promoting strategy.

In a relatively early study including some OECD developed countries, Barrell and Pain[11] show that there is evidence for significant spillovers and increased export performance from the presence of inward FDI. In a related work, Borensztein, Gregorio and Lee[12], using a panel of 69 developing countries in the 1970s and 1980s, found a positive and significant FDI effect on growth, only for countries holding a minimum threshold stock of human capital. These results suggest the importance of the absorptive capacity of the host economies in assimilating the advanced technologies transferred, usually from developed countries, a hypothesis thoroughly explored in relevant micro-studies. The authors conclude that the inflow of foreign direct investments has a positive impact on economic growth, but the sizes of these benefits depend on human capital resources available in the host country.

On the basis of studies concerning the link between the inflow of foreign direct investments and economic growth in Latin American countries, Bengoa and Sanchez-Robles[13] claim that the inflow of foreign direct investments has indeed a positive impact on the growth of the country. Both confirmed the hypothesis of Borensztein, De Gregorio, and Lee[12] that the ultimate impact of these investments on the rate of economic development of a country depends on many different conditions prevailing in the host country.

According to Hejazi and Safarian[14] FDI is a dominant channel for R\&D diffusion in OECD countries with its importance being higher than that of trade. However, de
Mello[7] argues that FDI is expected to boost long-term growth in the recipient economy and provides evidence that the extent to which FDI is growth-enhancing depends on the complementarity or substitutability between FDI and domestic investment. Furthermore, Balasubramanyam, Salisu, Sapsford[10] indicate that the size of the local market, the competitive environment and the availability of human capital are important for FDI to promote economic growth, while Elahee and Pagan[15] find positive evidence for the role of FDI in East Asian and Latin American countries, over the period 1985-1993.

The research of Barthelemy and Demurger[16], using panel data on 24 Chinese provinces in the period 1985-1996, provides evidence for a positive and mutual correlation between FDI and economic growth. Furthermore, they stress the importance of human capital for the adoption of foreign technologies and economic growth. Haveman, Lei and Netz[17], using data from 74 countries over the period 1970 -1989 and, find evidence for a positive growth effect of international integration indicators, such as openness, membership in a trade block or FDI.

By contrast, Zhang[18] in his study of 11 East Asian and Latin America countries during the period 1960-1997, finds a strong variation in the growth enhancing impact of FDI. According to his findings, FDI is more likely to boost economic growth in countries with particular characteristics like liberalised trade regimes, improved education, large export-oriented FDI and macroeconomic stability, e.g. Hong Kong, Indonesia, Singapore, Taiwan and Mexico.

Further evidence in favour of a positive growth FDI effect is provided by Ram and Zhang[19] using a cross section of 85 countries between the years 1990 and 1997, Campos and Kinoshita[20] utilizing panel data from 25 transition economies in the period 1990-1998, and Hansen and Rand[21] in a sample of 31 developing countries during 1970-2000. We should, also, note that the studies of Dollar and Kraay[22,23] have provided us with evidence that the effects of globalization were positive on growth in developing countries that implemented liberalized trade policies in the 1980s (Dimelis, Papaioannou)[24].

Alfaro, Chanda, Kalemli- Ozcan, Sayek[25], Durham[26] and Hermes and Lensink[27] provide evidence that only countries with a relatively well-developed financial market system enjoy substantial benefits - in the faster economic growth - from the inflow of foreign direct investments.

Using a production function approach employed with the panel data for the period 1992-2007, Verhorn and Vasarevic[28] prove that FDI and domestic investment are statistically significant determinants of economic growth in CEE countries as well as prudent fiscal and monetary policy.

The research of Damijan and Rojec[29] for six CEE countries (Czech Republic, Estonia, Hungary, Poland, Slovenia and Slovakia) shows that in the first decade of transition, in the period 1993-2001, in general productivity growth was positively correlated with FDI.

Landesmann[30] found out that in the Czech Republic, Hungary, Poland and Slovenia, foreign subsidiaries account 
for a higher share of sales in the medium and high-tech branches than in the low-tech or the resource-intensive ones, while the presence of FDI across other CEE countries is very uneven and so is its role in facilitating the upgrading of the CEE countries' industrial structures.

Moreover, the research of Damijan, Kostevc and Rojec[31,32] accounts for the importance of the 'global supply chains' concept for export restructuring and productivity growth in CEE countries in the period 1995-2007. Using industry-level data and accounting for technology intensity, they show that FDI has significantly contributed to export restructuring in the CEE countries. The effects of FDI are, however, heterogenous across countries. While more advanced core CEE countries succeeded in boosting exports in high-tech industries, non-core CEE countries stuck with export specialization in low-tech industries. This suggests that the FDI flow destination is of key importance. Their results show that export restructuring and economic specialization brought about by FDI during the last two decades in the CEE countries might matter a lot for their potential for the long-term productivity growth. High-tech industries have experienced substantially higher productivity growth and so have countries more successful in attracting FDI to these industries.

According to Baldwin[33] these productivity improvements due to FDI inflows may not necessarily predestine countries more lucky in attracting FDI to high-tech industries for the long-term higher development levels. FDI may easily pull out of the countries leaving them without much homegrown economic foundations. Yet, so far FDI certainly helped the CEE countries over the last decade and a half to grow faster in terms of TFP and to increase employment in high-tech industries. However, how sound and stable this specialization is in the long run is another question.

\section{Materials and Methods}

An attempt to assess the FDI impact on economic growth was made using the case of Poland which started the process of systemic transformation in 1989 and in 2004 became one of the EU member countries.

The reason for which the research into the FDI influence on economic growth in Poland was undertaken was to define the influence of these investments on economy over the transformation period of about 20 years.

The aim of these investigations was to determine whether the FDI impact on economic growth was significant or not. Our analysis covered the period of 18 years, from 1995 to 2012. The analysis starts with 1995 because it was the year when stabilization of economy was observed. Earlier years were characterized by a turbulent adjustment period. It was also possible to obtain full statistical data for the investigated period. The time series of variables were taken from the OECD and UNCTAD Internet databases and they were the annual data.
The paper took advantage of the methods used in the international economic literature, including econometric methods (of linear regression, CLS). Investigation of the FDI impact on economic growth was carried out with the use of the Cobb-Douglas production function.

The model estimation was carried out by means of the GRETL program. The model was verified with the use of the following tests: t-Student, F-Snedocor, heteroskedasticity, White's and LM. The degree of the model fit and collinearity of explanatory variables were estimated. Additionally, the Durbin-Watson test for autocorrelation was used for the verification of the econometric model.

In order to analyse stationarity of the analysed variables, an augmented Dickey-Fuller test (ADF) was employed. Normality of the distribution of residuals was assessed with the use of the Doornik-Hansen test.

\section{Model of Economic Growth}

In order to analyze the connection between the inflow of FDI and economic growth of the host country, we used the neoclassical model with employing the Cobb-Douglas production function. Following the paradigm of Hall and Mairesse[34] concerning the impact of innovation and technology transfer on economic growth, an aggregate Cobb-Douglas production function is specified, which incorporates four inputs, domestic capital (K), labour (L), foreign capital $(\mathrm{F})$ and information and communication technologies (ICT) capital:

$$
\mathrm{Y}_{\mathrm{it}}=\mathrm{A}_{\mathrm{it}} \mathrm{e}^{\mathrm{et}}\left(\mathrm{K}_{\mathrm{it}}\right)^{\alpha}\left(\mathrm{L}_{\mathrm{it}}\right)^{\beta}\left(\mathrm{F}_{\mathrm{it}}\right)^{\gamma}\left(\mathrm{ICT}_{\mathrm{it}}\right)^{\delta} \mathrm{e}^{\mathrm{uit}}
$$

where the subscripts of $i$ and $t$ denote country and year, respectively; $Y$ measures gross output of each country, while $K$ and $F$ are taken to represent non-ICT capital. Furthermore, $A$ and $c$ are constant terms, the parameters $\alpha, \beta, \gamma$ and $\delta$ are the elasticities of domestic capital, labour, foreign capital and ICT with respect to output and finally $u_{i t}$ is the error term capturing unobserved variations between countries and over time (Dimelis, Papaioannou)[24].

Following a common practice in literature dealing with economic growth, the equation is further augmented by the lagged level of the dependent variable (lagged level of output per worker in its logarithmic scale) to capture convergence effects among countries (Barro)[35]. The factors used in the augmented function can be transparency index (TI), government consumption (GOV) and openness of trade (OPENNESS) (imports plus exports as a share of GDP).

\subsection{Basic Model of Economic Growth for Poland}

In this paper the Cobb-Douglas production function was used to analyse the effect of domestic expenditure and foreign investment on changes in the GDP value. The Cobb-Douglas production function used is expressed by the following formula:

$$
\mathrm{Y}_{\mathrm{t}}=\mathrm{f}\left(\mathrm{GFCFt} \text {, Employ.t, } \mathrm{FDI}_{\mathrm{t}}, \mathrm{R} \& \mathrm{D}_{\mathrm{t}}\right)
$$


where:

$\mathrm{Y}_{\mathrm{t}}$ - Gross Domestic Product, GDP (million USD); $\mathrm{GFCF}_{\mathrm{t}}$ - Gross Fixed Capital Formation (million USD);

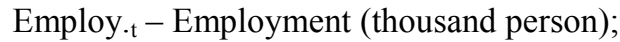

$\mathrm{FDI}_{\mathrm{t}}-$ Foreign Direct Investment (inward) (million USD);

$R \& D_{t}-$ Gross Domestic Expenditure on R\&D (million USD, 2005 constant prices and PPPs);

$\mathrm{t}$ - analyzed period.

Adoption of independent variables for GDP results from the assumptions of the Cobb-Douglas component functions and from similar investigations taking into account the FDI impact on economic growth in the country hosting investments, e.g. investigations of Dimelis, Papoioannou[24], Roman, Padureanu[36], Driffield, Jindra[37].

Prior to the estimation of the model the variables were logarithmed, the significance of structural parameters (t-distribution, F-Snedocor test) was examined as well as the goodness of fit of the model (the coefficient of determination, $\mathrm{R}^{2}$ ) and selection of variables for the model (correlation matrix).

In order to analyse the correlations between the dependent variable being GDP and independent variables, Pearson's correlation coefficient was calculated. The highest positive linear correlation occurred between GFCF and GDP, at the level $\mathrm{R}^{2}=0.9515$, compared with a lower correlation between expenditure on $R \& D$ and the GDP value, where $\mathrm{R}^{2}=0.9104$. The remaining variables revealed a significantly lower linear correlation (Table 1).

In order to analyse stationarity of the analysed variables, an augmented Dickey-Fuller test (ADF) was employed. For all analysed variables a unit root $\mathrm{a}=1$ was noted; integration row I(1), which indicates non-stationarity of time series.

In the input version of the estimated model the variable significant at 5\% significance level was expenditure on R\&D, whereas FDI inward, GFCF and Employment turned out to be insignificant. The coefficient of determination equaled $\mathrm{R}^{2}=0.9555$, which proved a high level of explanation. The Fisher-Snedocor distribution implies that the model's goodness of fit is adequate, as $\mathrm{F}>\mathrm{F}^{*}$, i.e. $137.538>3.885$ (Table 2).

Normality of the distribution of residuals was assessed with the use of the Doornik-Hansen test which confirmed that the distribution of residuals has the features of normal distribution. Then White's general test was performed which showed that heteroskedasticity of residuals is not present: according to White's test $\mathrm{TR}^{2}<\chi^{2}$, where $\mathrm{TR}^{2}=17.295$ and $\chi^{2}(10 \% ; 14)=21.06$; with $p$ value $=0.2408$.

White's test for non-linearity (logarithms) was used for the assessment of the linearity of the analytical form of the model. It confirmed validity of the linear form model. According to LM test statistic (logarithms) $\mathrm{TR}^{2}<\chi^{2}$, where $\mathrm{TR}^{2}=11.8256$ and $\chi^{2}(1 \% ; 4)=13.28$; with $\mathrm{p}$ value $=0.01869$.

Following statistical and factual verification of the basic model of economic growth for Poland in the period 1995-2012 were estimated ultimate results. The significant independent variables for GDP became the variables: GFCF and expenditure on R\&D. The variables Employment and later FDI inward were eliminated by means of estimation. The coefficient of the model determination was maintained at a high level $\mathrm{R}^{2}=0.948$ (Table 3).

The estimation results obtained correspond, among others, to those from the research by Dimelis and Papaioannou[24], who examined 42 developed and developing countries in the period 1993-2001. The research revealed, among others, that foreign capital in the form of FDI inward was significant for the rate of economic growth only in the developed countries, whereas in developing countries, including Poland, it was insignificant.

\subsection{Augmented Model of Economic Growth for Poland}

The formula of the Cobb-Douglas component functions used for the investigation of the rate of economic growth is often extended by additional independent variables, e.g. labour productivity index per person employed, rate of ICT capital per worker, the government expenditure to GDP ratio, openness of trade index and transparency index (e.g. Dimelis, Papaioannou)[24].

In order to verify accuracy of Model I, an augmented model was developed. This augmented model of economic growth for Poland for the years 1995-2012 consists of seven variables, and presumes that the dynamics of GDP is a function of the country's gross fixed capital formation, the labour productivity of the total economy, general government expenditures, gross domestic expenditures on R\&D, FDI inward and openness of trade index.

Models II includes the following variables:

$Y_{t}=f\left(G F C F_{t}, L F_{t}, G_{t}\right.$ GOV.EXP, R\& $D_{t}$, FDIt, Openness $\left.s_{t}\right)$

where:

$Y_{t}-$ GDP growth (market prices, percentage change from previous year);

$\mathrm{GFCF}_{\mathrm{t}}$ - Gross Fixed Capital Formation, housing, volume (percentage);

LPTE $_{\mathrm{t}}-$ Labour Productivity of the Total Economy (percentage);

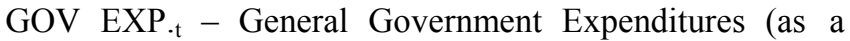
percentage of GDP);

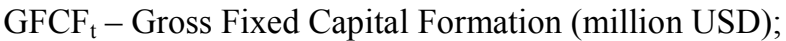

$R \& D_{t}-$ Gross Domestic Expenditure on $R \& D$ (as a percentage of GDP);

$\mathrm{FDI}_{\mathrm{t}}-$ Foreign Direct Investment Inward (as a percentage of GDP);

Openness $_{t}$ - Openness of Trade Index (imports plus exports as a share of GDP).

$\mathrm{t}$ - analyzed period.

The time series of the above variables also came from OECD and UNCTAD databases; these were annual data expressed in percentages.

In order to analyse significance of the augmented model, F-Snedocor test was employed. The model consists of significance variables because it met the condition: $\mathrm{F}>\mathrm{F}^{*}$, 
i.e. $10.457>4.60$.

The augmented Model II in its original version revealed the degree of GDP explanation by explanatory variables at the level of $57.51 \%$ - coefficient of determination $\mathrm{R}^{2}=$ 0.5751 . The test for normality of distribution of residuals confirmed that residuals demonstrate characteristics of normal distribution. The Doornik-Hansen test indicated that Chi-square $(2)=0.238$ with $\mathrm{p}$ value $=0.88798$, where $\mathrm{p}>$ $\alpha=0.10$. According to Jargue-Bera test met the condition, because JB $=0.238<\chi^{2}(2)=4.605$. Durbin-Watson Statistic, $\mathrm{DW}=1.834$, by $\mathrm{d}_{\mathrm{L}}=0.603$ and $\mathrm{d}_{\mathrm{U}}=2.257$. The model fulfilled the autocorrelation test because $\mathrm{d}_{\mathrm{L}} \leq \mathrm{DW} \leq 4-\mathrm{d}_{\mathrm{L}}$; $0.6030 \leq 1.834 \leq 3.397$.

Following statistical and factual verification, elimination of insignificant variables: LPTE, Openness, FDI inward and expenditure on $R \& D$. The ultimate augmented model of economic growth for Poland assumed the form with two independent variables, i.e. GOV.EXP at t-distribution = 2.541 and GFCF $t$-distribution $=1.694$. This means that only government expenditure was statistically significant at $\alpha=0.05$ (Table 4).

Table 1. Correlation coefficient of GDP and GFCF, FDI inward, Employment and R\&D in Poland in the period 1995-2012

\begin{tabular}{|c|c|c|c|c|c|}
\hline GDP & GFCF & $\begin{array}{c}\text { FDI } \\
\text { inward }\end{array}$ & Employment & R_D & GDP \\
\hline 1.0000 & 0.9515 & 0.8301 & 0.3858 & 0.9104 & GFCF \\
\hline & 1.0000 & 0.8492 & 0.2548 & 0.8380 & $\begin{array}{c}\text { FDI } \\
\text { inward }\end{array}$ \\
\hline & & 1.0000 & 0.3177 & 0.6931 & 0.6414 \\
\hline
\end{tabular}

Source: author`s own calculations on the basis of OECD[38] and UNCTAD[2], GRETL program

Table 2. Model I. Estimation of GDP values in Poland by the CLS method for the period 1995-2012, input data

\begin{tabular}{|c|c|c|c|c|c|}
\hline & Coefficient & Standard error & t-distribution & $\mathrm{p}$ value & $\alpha$ \\
\hline Const & 11.1582 & 4.52875 & 2.464 & 0.0285 & $*$ * \\
\hline GFCF & 0.252627 & 0.146909 & 1.720 & 0.1092 & 0.2100 \\
\hline $\begin{array}{c}\text { FDI } \\
\text { inward }\end{array}$ & 0.0540138 & 0.0409608 & 1.319 & 0.2972 & \\
\hline $\begin{array}{c}\text { Employ } \\
\text { ment }\end{array}$ & -0.546617 & 0.503324 & -1.086 & 0.0136 & $* *$ \\
\hline R_D & 0.526669 & 0.184722 & 2.851 & \\
\hline
\end{tabular}

**, where $\alpha=0,05$. One-year long lag for GDP data. GDP data for the years 1995-2012. GFCF, FDI inward, Employment and R\&D data for the years 1994-2011.

Source: author's own calculations on the basis of OECD[38] and UNCTAD[2], GRETL program.

Table 3. Model I. Estimation of the GDP value in Poland by the CLS method, for the period 1995-2012, final data

\begin{tabular}{|c|c|c|c|c|c|}
\hline & Coefficient & Standard error & t-distribution & p value & $\alpha$ \\
\hline const & 5.98941 & 0.441199 & 13.58 & $7.87 \mathrm{e}-010$ & $* * *$ \\
\hline GFCF & 0.465994 & 0.0583608 & 7.9847 & $2.99 \mathrm{e}-05$ & $* * *$ \\
\hline R_D & 0.351678 & 0.0996573 & 3.529 & 0.0030 & $* * *$ \\
\hline
\end{tabular}

***, where $\alpha=0,01$.

Source: author`s own calculations on the basis of OECD[38] and UNCTAD[2], GRETL program.

Table 4. Model II Estimation of the GDP value in Poland by CLS method, for the period 1995-2012, final data

\begin{tabular}{|c|c|c|c|c|c|}
\hline & Coefficient & Standard error & t-distribution & p value & $\alpha$ \\
\hline const & -13.5545 & 6.76756 & -2.0029 & 0.06361 & $*$ \\
\hline GFCF & 0.0701446 & 0.0414198 & 1.6935 & 0.11102 & \\
\hline GOV.EXP & 0.391548 & 0.154064 & 2.5415 & 0.02258 & $* *$ \\
\hline
\end{tabular}

$* *$, where $\alpha=0,05$.

Source: author's own calculations on the basis of OECD[38] and UNCTAD[2], GRETL program. 


\section{Discussion}

On the basis of the data from Tables 3 and 4, it is clear that FDI was not a significant factor determining GDP growth in Poland in the period 1995-2012. The relatively linear correlation between the FDI inflow dynamics and the economic growth was confirmed. On the other hand, it was found out that in Poland the gross fixed capital formation, general government expenditures and gross domestic expenditures on R\&D have the largest impact on GDP growth.

Similar research results regarding FDI impact on economic growth in developing countries and transaction economies have been obtained by other authors, e.g. de Mello[7], Carkovic and Levine[39], Misztal[40] and Dimelis and Papaioannou[24].

De Mello[7] in a study of 32 developed and developing countries during the period 1970-1999, finds only weak evidence for FDI effect on economic growth.

Carkovic and Levine[39], analyzed the relationship between the FDI inflow and economic growth on the basis of the panel data, covering 72 developed and developing economies. These studies were carried out using ordinary least squares (OLS) and a generalized method of moments (GMMS). The results of these studies show insignificant connection between the inflow of foreign direct investments and economic growth in analyzed countries.

On the basis of an analysis of the role of FDI in stimulating economic growth in Romania in the years 2000-2009, Misztal[40] confirmed a relatively important linear correlation between the dynamics of FDI inflow and the dynamics of economic growth in Romania. VAR model estimations demonstrated that the FDI inflow was one of the key factors which substantially determined GDP in Romania during the period 2000-2009. On the other hand, it was also found out that at the same time the changes in employment had the largest impact on GDP growth in Romania. Thus, the positive and significant influence of FDI on the dynamics of GDP growth in Romania has been confirmed, but taking into account other determining factors, FDI was not the most significant cause of economic growth in Romania.

Besides the existing empirical evidence shows the importance of FDI in fostering investment in Information and Communication Technologies (ICTs) in developing economies (e.g. Gholami, Lee, Heshmati)[41]. While developed countries are expected to adopt more quickly general purpose technologies (GPTs) more quickly developing countries tend to imitate them with lower costs because of learning and experience effects. Furthermore, ICT is expected to have a positive impact on FDI as it creates opportunities, especially for developing countries that are located away from technologically advanced countries, to free themselves from geographical limitations and become more attractive to foreign investors (Dimelis, Papaioannou)[24].

Dimelis and Papaioannou[24] researched possible effects stemming from FDI and Information and Communication
Technologies (ICT) on productivity growth. Their analysis is based on panel data covering a sample of 42 developing and developed countries during the period 1993-2001. The results regarding growth indicate that ICT considerably contributed to growth in both developed and developing countries. On the contrary, the FDI contribution was relatively low. The econometric results showed a positive and significant impact of ICT in all groups, the effect being larger among developing countries. Positive and significant FDI effects were found in the group of developed countries, and positive but insignificant, among the developing ones.

Most results of macroeconomic analyses suggest that the ability of individual economies to benefit from positive effects of FDI on economic growth are limited by conditions prevailing in the host country, such as the level of development, local financial markets and the level of education of the population which determines the absorption capacity. Moreover, many empirical studies on the role of FDI in a host country suggest that the inflow of these investments is an important source of capital, a supplement of national private investments and, usually, it involves a new employment and import technology to the host country, which leads then to a higher growth of the economy (Chowdhury, Mavrotas[42]).

We should point out that FDI is considered as an important channel for direct technology diffusion (Blomstrom and Kokko)[43]. Particularly, in developing countries, FDI is probably the most important channel for technology transfer because of the scarcity of financial resources and the urgent need for reconstruction. Within this framework it is expected that FDI will indirectly contribute to economic growth by accelerating the diffusion of general purpose technologies (GPTs).

The macro-economic literature indicates that local structures, institutions and capital endowments are important for a host country to take advantage of FDI (Alfaro, Chanda, Kalemli-Ozcan, Sayek)[25]. In particular, there is evidence that FDI contributes to a host country's productivity when the technology gap is not large and when a sufficient level of absorptive capacity exists in the host country e.g. Kokko[44], Borensztein, Gregorio and Lee[12]. Other conditions enhancing the FDI effect on economic growth of a host country include: the level of financial development, local credit constraints and openness of trade (OPEN) (Hermes and Lensink[45], Alfaro, Chanda, Kalemli-Ozcan, Sayek[46]; Aghion, Howitt, Mayer-Foulkes[47].

Overall the econometric results indicate that developing countries have the potential to take advantage of ICT. With respect to FDI, Lall and Narula[48] note that FDI cannot be a driving force for the long-term economic growth of the host county without the existence of local capabilities and without the assistance of governments in promoting policies favourable for FDI. Such policies might be oriented to (OPEN) openness of trade and financial development. Further policies will lead to the increase of competition in the high-technology sector, the increase of Internet diffusion, the development of telecommunications infrastructure, and the 
establishment of an adequate legal and regulatory framework. Moreover, hight-level specialized training should be brought into focus, however without overlooking basic education because the encouragement of training is more effective when basic skills are already available (Dimelis and Papaioannou)[24].

The level of education (qualification), a minimum level of technology and macroeconomic stability, favourable business environments, low country risk, even the sector where FDI take place can influence the link between FD and economic growth.

\section{Conclusion}

In theoretical literature and empirical research there are many different explanations of the role and impact of FDI on host states. In the 1990s empirical studies showed mainly a positive FDI impact on economic growth. But that research concerned developed countries. Later, in the 2000s, empirical studies with concerned both developed and developing countries showed different effects: positive, negative, bi-directional as well as no effects.

The research in question showed one important fact, namely, that the ability of individual economies to take advantage of positive externalities related to the FDI inflow are limited by conditions prevailing in the host country, such as: the minimum threshold level of human capital, of improved domestic infrastructures, as well as of a developed local financial system. There is evidence that FDI contributes to the host country's productivity when the "technology gap" is not large and when a sufficient level of absorptive capacity exists in the host country.

The research conducted in Poland reveals that in the period 1994-2012 a linear correlation existed between the FDI inflow and growth (Pearson's coefficient $\mathrm{R}=0.8317$ ), however, according to a model estimated with the use of the CLS method, FDI was not a significant factor determining GDP growth. The really significant factors in the basic model of economic growth were gross domestic expenditure on fixed capital and expenditure on $R \& D$.

The augmented version of the Cobb-Douglas function model for the years 1995-2012 demonstrates that the only significant factor was government spending at $5 \%$ significance level. The remaining variables were insignificant.

This result can testify to low effectiveness of FDI on the Polish market, lack of reinvestment, transfer of income abroad, hence a current account balance for Poland is negative. The reason for that is unfulfilled conditions of the positive FDI impact on the economy of the host country, e.g. technological gap.

The negligible effect of FDI on GDP growth in Poland in the years 1995-2012 corresponds to similar results of the research conducted for developing countries (including those undergoing systemic transformations) among others by de Mello[7], Carkovic and Levine[39], Misztal[40], Dimelis and Papaioannou[24].

The insignificant impact of FDI on economic growth in Poland and other developing countries can also be explained by several insufficiencies that act as barriers to FDI and hinder its impact on economic growth.

\section{REFERENCES}

[1] NBP, Zagraniczne Inwestycje Bezpośrednie w Polsce za Lata 1994-2012, Online available from http://www.nbp.pl/home.aspx?f=/publikacje/zib/zib.html

[2] UNCTAD, UNCTADStat.2012, Online available from http://unctadstat.unctad.org

[3] NBP, Polska: Międzynarodowa Pozycja Inwestycyjna, Departament Statystyki NBP, Online available from http://www.nbp.pl/home.aspx?f=/statystyka/m_poz_inwest.h tml

[4] R. M. Solow, Neoclassical Growth Theory. In Handbook of Macroeconomics, Vol. I, ed., by J. B. Taylor and M. Woodford. Amsterdam: Elsevier, 1999.

[5] D. Herzer, S. Klasen and F. Howak-Lehmann, In Search of FDI-led Growth in Developing Countries: The Way Forward, Economic Modelling, 25(5), 793-910, September 2008

[6] J. Aizeman, L. Noy, FDI and Trade - Two Way Linkages? The Quarterly Review Of Economics, 46(3), 317-337, July 2006.

[7] L. R. de Mello, Foreign Direct Investment-Led Growth: Evidence From Time Series and Panel Data. Oxford Economic Papers 51(1), 133-151, 1999.

[8] T. Addison, A. Heshmati, The New Global Determinants of FDI Flows to Developing Countries: The Importance of ICT and Democratization. Helsinki, Finland. UNU-WIDER Discussion Paper No.45, 1-29, 2003.

[9] D. Vintila, R. Zaharia, Foreign Direct Investments and Economic Growth in Romania, 7th International Scientific Conference, Business and Management 2012, Vilnius Gediminas Technical University, Lithuania, 2012, http:/www.bm.vgtu.lt, ISSN 2029-929X online, ISBN 978-609-457-116-9 CD., p. 248, 2012.

[10] V. N. Balasubramanyam, M. Salisu and D. Sapsford, Foreign Direct Investment as an Engine of Growth. Journal of International Trade and Economic Development 8(1), 27-40, 1999.

[11] R. Barrell, N. Pain, Foreign Direct Investment, Technological Change and Economic Growth Within Europe. Economic Journal 107(445), 1770-1785, 1997.

[12] E. Borensztein, J. Gregorio and J. W. Lee, How Does Foreign Direct Investment Affect Economic Growth? Journal of International Economics 45(1), 115-135, 1998.

[13] M. Bengoa, B. Sanchez-Robles, Foreign Direct Investments, Economic Freedom and Growth: New Evidence From Latin America, European Journal of Political Economy, No.19, 529-545, 2003. 
[14] W. Hejazi, A. Safarian, Trade, Foreign Direct Investment and R\&D Spillovers. Journal of International Business Studies 30(3), 491-511, 1999.

[15] M. N. Elahee, J. A. Pagan, Foreign Direct Investment and Economic Growth in East Asia and Latin America. Journal Of Emerging Markets 4(1), 59-67, 1999.

[16] J. C. Barthelemy, S. Demurger, Foreign Direct Investment And Economic Growth: Theory and Application to China. Review Of Development Economics 4(2), 140-155, 2000.

[17] J. Haveman, V. Lei, And J. Netz, International Integration and Growth: A Survey and Empirical Investigation. Review of Development Economics 5(2), 289-311, 2001.

[18] K. Zhang, Does Foreign Investment Promote Economic Growth? Evidence From East Asia and Latin America. Contemporary Economic Policy 19(2), 175-185, 2001.

[19] R. Ram, K. Zhang, Foreign Direct Investment and Economic Growth: Evidence From Cross-Country Data for the 1990s. Economic Development and Cultural Change 51(1): 205-215, 2002.

[20] N. Campos, Y. Kinoshita, Foreign Direct Investment as Technology Transferred: Some Panel Evidence From The Transition Economies. Manchester School 70(3), 398-419, 2002.

[21] H. Hansen, J. Rand, On The Causal Links Between FDI and Growth in Developing Countries. The World Economy 29(1), 21-41, 2006.

[22] D. Dollar, A. Kraay, Institutions, Trade and Growth. Journal of Monetary Economics 50(1), 133-162, 2003.

[23] D. Dollar, A. Kraay, Trade, Growth and Poverty. The Economic Journal 114(2), 22-49, 2004.

[24] S. P. Dimelis, S. K. Papaioannou, FDI and ICT Effects on Productivity Growth: A Comparative Analysis of Developing and Developed Countries, The European Journal of Development Research and Training Institutes (EADI), Geneva, UK, Vol.22, No.1, 79-96, February 2010.

[25] L. Alfaro, A. Chanda, S. Kalemli-Ozcan, S. Sayek, How Does Foreign Direct Investments Promote Economic Growth? Exploring The Effects of Financial Markets on Linkages, NBER Working Paper Series, No.12522, 1-58, 2006.

[26] K. B. Durham, Absorptive Capacity and The Effects of Foreign Direct Investments and Equity Foreign Portfolio Investments on Economic Growth, European Economic Review, No.48, 285-306, 2004.

[27] N. Hermes, R. Lensink, Foreign Direct Investments, Financial Development and Economic Growth, Journal of Development Studies, No.40, 2003.

[28] C. L. Vehorn, A. Vasarevic, FDI and Macroeconomic Policies, Central and Eastern European Countries, Zagreb International Review of Economics \& Business, 14(1), 23-34, 2011.

[29] J. P. Damijan, M. Rojec. Foreign Direct Investment and Catching up of New EU Member States: Is There a Flying Geese Pattern. Applied Economics Quarterly, No.53(2), 91-117, 2007.

[30] M. A. Landesmann, Structural Features Of Economic
Integration in an Enlarged Europe: Patterns Of Catching-Up and Industrial Specialisation. European Economy No.181. European Commission, Brussels, 1-62, 2003.

[31] J. P. Damijan, C. Kostevec, M. Rojec, Global Supply Chains at Work in Central And Eastern European Countries: Impact of FDI on Export Restructuring and Productivity Growth, LICOS Discussion Paper Series, No.332/2013, Belgium, $1-36,2013$

[32] J. P. Damijan, M. Rojec, B. Majcen and M. Knell, Impact of Firm Heterogeneity on Direct and Spillover Effects of FDI: Micro Evidence From Ten Transition Countries. Journal of Comparative Economics No.41(3), 895-922, 2013.

[33] R. Baldwin, Global Supply Chains: Why They Emerged, Why They Matter, and Where They are Going. CTEI Working Papers CTEI-2012-13. The Graduate Institute Geneva, Centre for Trade and Economic Integration, 1-35, July 2012.

[34] B. H. Hall, J. Mairesse, Exploring the Relationship Between R\&D and Productivity in French Manufacturing Firms. Journal of Econometrics 65(1), 263-293, 1995.

[35] R. Barro, Economic Growth in a Cross Section Of Countries. Quarterly Journal of Economics 106(2), 407-433, 1991.

[36] M. D. Roman, A. Padureanu, Models of Foreign Direct Investments Influence on Economic Growth. Evidence from Romania, International Journal of Trade, Economics and Finance, Vol.3, No.1, 1-5, February 2012.

[37] N. Driffied, B. Jindra, Challenging The Production Function Approach to Assess The Developmental Effects of FDI, European Journal of Development Research and Training Institutes (EADI), Geneva, UK, Vol.24, No.1, 32-37, February 2012

[38] OECD, OECDdstat, 2012, Online available from http://www.oecd.org./statistics/

[39] M. Carkovic, R. Levine, Does Foreign Direct Investments Accelerate Economic Growth?iIn: H. T. Moran, E. Graham, M. Blomstrom (Eds.), Does FDI Promote Development?, Institute for International Economics, Washington, 195-220, 2002.

[40] P. Misztal, Foreign Direct Investments as a Factor for Economic Growth in Romania, Review of Economic and Business Studies, Alexandru Ioan Cuza University, Faculty of Economics and Business Administration, Issue 5, 39-53, June 2010.

[41] R. Gholami, T. Lee and A. Heshmati, The Causal Relationship Between Information and Communication Technology and Foreign Direct Investment. The World Economy 29(1), 43-62, 2006.

[42] A. Chowdhury, G. Mavrotas, FDI and Growth: What Causes What? The World Economy, No. 29(1), 9-19, 2006.

[43] M. Blomstrom, A. Kokko, How Foreign Investment Affects Host Countries. Washington DC, USA. World Bank Working Paper No.1745, 1997.

[44] A. Kokko, Technology, Market Characteristics and Spillovers. Journal of Development Economics 43(2), 279-293, 1994.

[45] N. Hermes, R. Lensink, Foreign Direct Investment, Financial 
Development and Economic Growth. Journal of Development Studies 40(1), 142-163, 2003.

[46] L. Alfaro, A. Chanda, S. Kalemli-Ozcan, And S. Sayek, FDI and Economic Growth, The Role of Local Financial Markets. Journal of International Economics 64(1), 89-112, 2004.

[47] P. Aghion, P. Howitt and D. Mayer-Foulkes, The Effect of
Financial Development on Convergence: Theory and Evidence. Quarterly Journal of Economics 120(1), 173-222, 2005.

[48] S. Lall, R. Narula, Foreign Direct Investment and Its Role in Economic Development: Do We Need a New Agenda? The European Journal of Development Research 16(3), 447-464, 2004. 